\title{
Literacy Transition in Scheduled Caste Population: A Study of Rural Haryana
}

\author{
Vishal Singh \\ Research Scholar, Department of Geography, Maharishi Dayanand University, Rohtak, Haryana, India
}

\begin{abstract}
The study examines the trend of literacy and gap in literacy between male-female (1991 to 2011) in comparative mode between Haryana and India at the level of scheduled caste population (sc) in rural area. The study also analysis the spatial pattern of literacy as well as gender disparity in literacy at district level in Haryana. Correlation between literacy and other selected indicators, also find out. The study reveals that rural literacy rate in sc is remaining high in Haryana from India at all levels (total, male and female) during the entire time period (1991-2011) and its growth rate is recorded very high and almost same in both at all levels during the successive censuses. Gap in literacy between male-female is decreased eight per cent in Haryana and six per cent in India during the entire time period however, it is high almost 20 per cent in both at current time. Sirsa, Fatehabad, Kaithal, Hisar, Jind and Karnal have low literacy while all central, south-west and southern districts (except Gurgaon and Rohtak) have high gender disparity in literacy.
\end{abstract}

Keywords: comparative trend and gender gap in literacy, spatial pattern, gender disparity and Correlation Matrix.

\section{Introduction}

Literacy is defined as the ability of people to read and write a simple message in any language with some understanding. It is not mandatory that to be treated as a literate, a person should have received any formal education or acquired any minimum educational standard. Literacy status can be acquired through adult literacy classes or by attending any non-formal education system. Person who are unfortunately blind and read in Braille are also treated as literates. From 1991 census, children below seven years are ignored when working out literacy rate in the country and the population aged seven years and above only would be classified as literate or illiterate. The proportion of literate persons in population is known as literacy level and the process of dissemination of literacy among the people in a society known as literacy transition. Literacy is related to all type of development which prepares the individual for full participation in a rapidly changing social and economic order. Better literate person is more likely to secure qualitative employment, more earnings, long and healthy life and cleaner and sustainable environment. An overall progress in literacy is necessary in a country, equally important is its distributional spread in all its areas - towns and villages, social classes and the two sexes (Gosal, 1979). The status of literacy varies significantly across different regions and different communities depending on the socio-economic and demographic characteristics as well as on the magnitude and direction of modernization, urbanization and industrialization. In this context, the study examines the status of literacy in scheduled caste population (sc) of rural Haryana.

\section{Study Area}

It is a study of literacy transition (1991-2011) in Scheduled Caste Population of rural Haryana. Haryana is located on the north-western side of Indian Union. It consists of 21 districts at the time of census (2011) enumeration. It is extended from $27^{\circ} 39^{\prime}$ north to $30^{\circ} 55^{\prime} 5^{\prime}$ 'north latitudes and $74^{\circ} 27^{\prime} 8^{\prime \prime}$ east to $77^{\circ} 36^{\prime} 5^{\prime \prime}$ east longitudes. It is situated to the south- east and south of Punjab. Similarly
Uttar Pradesh is situated in east of Haryana while Haryana adjoining with national capital. Rajasthan is located in south and south-west of Haryana. Geographically, Ghaggar river makes the south-west boundary of Haryana which divides Punjab from Haryana. Siwalik hills are situated in north part of Haryana while river Yamuna flows in east of Haryana which separates Uttar Pradesh from Haryana. Arawali hills are situated in south Haryana.

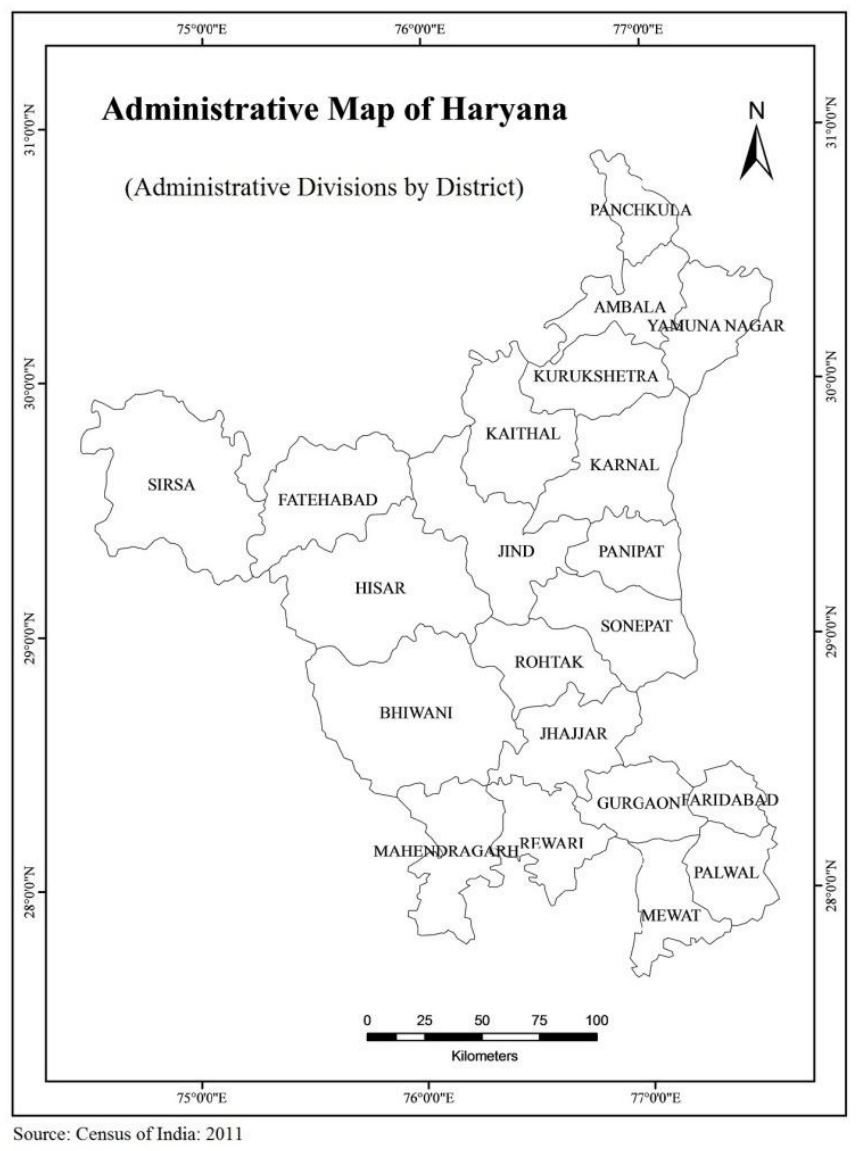

Figure 1

Volume 6 Issue 1, January 2017 www.ijsr.net 


\section{International Journal of Science and Research (IJSR)}

ISSN (Online): 2319-7064

Index Copernicus Value (2015): 78.96 | Impact Factor (2015): 6.391

\section{Objectives of the Study}

(1) To examine comparative trend of literacy and gap in literacy by sex (1991-2011) in scheduled caste population of rural area between Haryana and India.

(2) To represent the spatial pattern of literacy at district level.

(3) To identify gender disparity in literacy at district level.

(4) To examine the correlation between literacy and selected indicators of socio-economic and demographic.

\section{Data and Methodology}

In this study, data have obtained from Census of India 1991, Primary census Abstract, Scheduled caste table. Census of India 2001, Social and Cultural Tables, Table C8. Census of India 2011, Social and Cultural Tables, Table C-8,SC. for showing comparative trend of literacy and gap in literacy by sex between Haryana and India as well as spatial pattern and gender disparity in literacy at district level in Haryana. For calculate correlation, data are used from Census of India 2011, Social and Cultural Tables, Table C-8,SC. Data of urbanization are collected from urbanization report which is published by Town and Country Planning Organization, Ministry of Urban Development, Government of India, January 2012.

Methodology is central to any research work which helps in scientific description and explanation of reality. A systematic approach has been followed in present study. The data have been analyzed keeping state and district as a unit of observation. Absolute figures are converted into percentages and these percentages are processed for necessary cartographic representations and interpretation. Pearson's correlation is used. Requisite maps have been drawn with the help of Arc GIS software. Correlation is calculated with the help of SPSS software. Sopher's Disparity Index (1980) modified by Kundu and Rao (1985) as given below, has been used to compute gender disparity in literacy at district level.

Ds $=\log \left(\mathrm{x}_{2} / \mathrm{x}_{1}\right)+\log \left(200-\mathrm{x}_{1} / 200-\mathrm{x}_{2}\right)$

Here,

Ds $=$ Gender Disparity index

$\mathrm{X}_{2}=$ male literacy rate

$\mathrm{X}_{1}=$ female literacy rate

Table 1: Literacy Rate and Gender Gap in Scheduled Caste Population of Rural Area (1991-2011)

\begin{tabular}{|c|l|c|c|c|}
\hline State and Country & Literacy Rate and Gender Gap in Literacy & 1991 & 2001 & 2011 \\
\hline \multirow{5}{*}{ India } & Total Literacy Rate & 33.25 & 51.16 & 62.85 \\
\cline { 2 - 5 } & Male Literacy Rate & 45.95 & 63.66 & 72.58 \\
\cline { 2 - 5 } & Female Literacy Rate & 19.46 & 37.84 & 52.56 \\
\cline { 2 - 5 } & Gap betweenin Male-Female Literacy Rate & 26.48 & 25.81 & 20.01 \\
\hline \multirow{5}{*}{ Haryana } & Total Literacy Rate & 37.67 & 54.13 & 65.75 \\
\cline { 2 - 5 } & Male Literacy Rate & 50.62 & 65.88 & 75.10 \\
\cline { 2 - 5 } & Female Literacy Rate & 22.48 & 25.64 & 55.20 \\
\cline { 2 - 5 } & Gap between Male-Female Literacy Rate & 28.14 & 25.24 & 19.90 \\
\hline
\end{tabular}

Source: Census of India 1991, Primary census Abstract, Scheduled caste table.

Census of India 2001, Social and Cultural Tables, Table C-8.

Census of India 2011, Social and Cultural Tables, Table C-8, SC

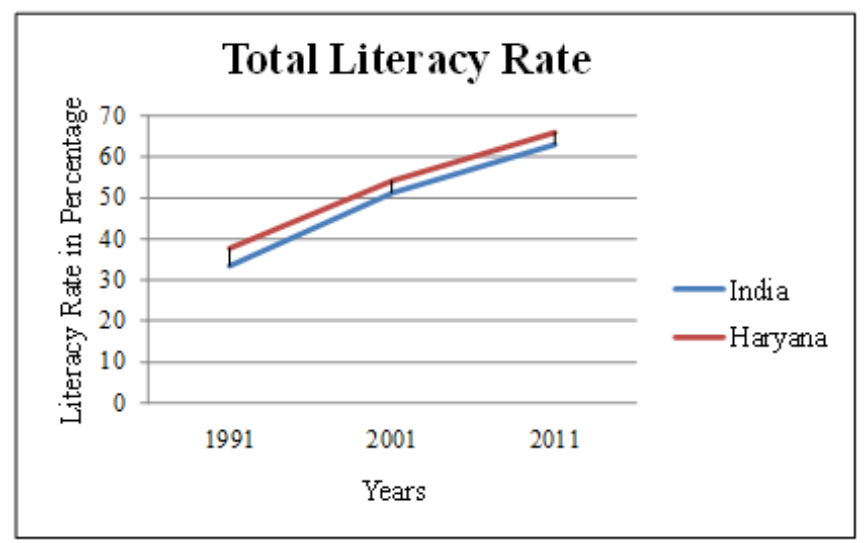

Figure 2

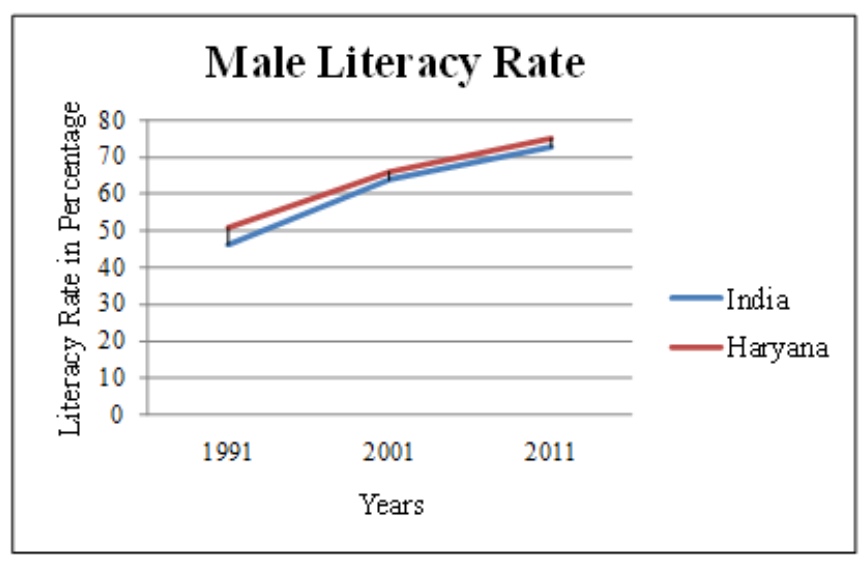

Figure 3 
International Journal of Science and Research (IJSR)

ISSN (Online): 2319-7064

Index Copernicus Value (2015): 78.96 | Impact Factor (2015): 6.391

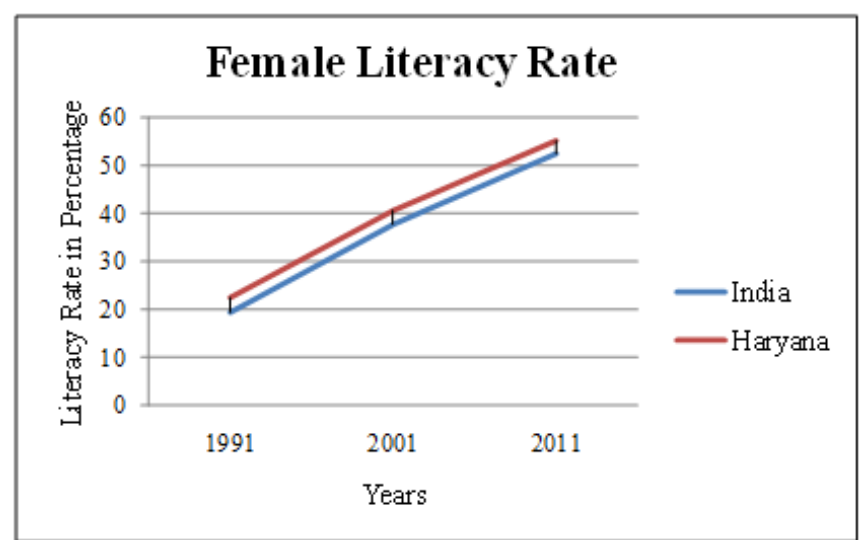

Figure 4

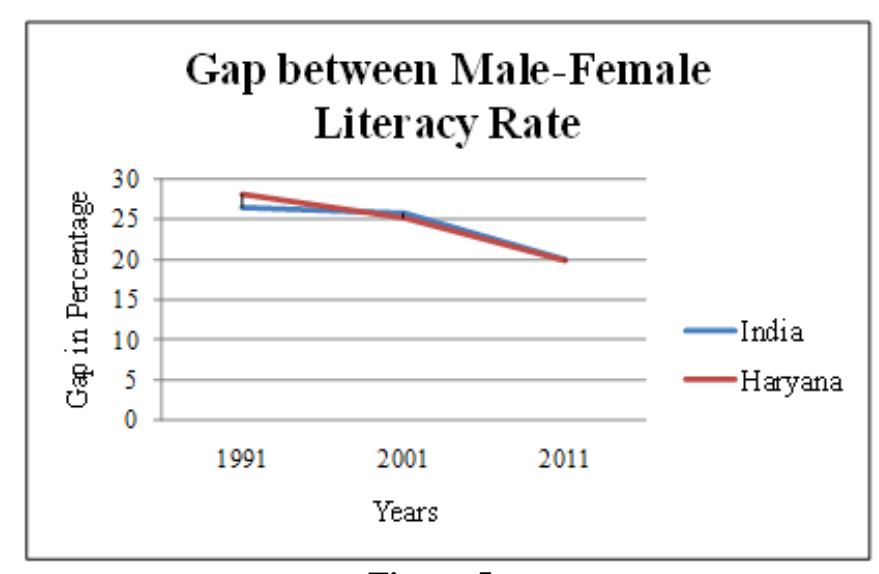

Figure 5

\section{Trend of Literacy and Gender Gap}

Rural literacy rate in Scheduled Caste Population is remaining high in Haryana from India at all levels (total, male and female) during the entire time period (1991-2011) and its growth rate is recorded very high and almost same in both at all levels during the successive censuses. Gap in literacy between male-female is decreased from 28.14 per cent to 19.90 per cent in Haryana while in India, it decreased from 26.48 per cent to 20.01 per cent during the entire time period.

Table 2: Literacy Rate and Gender Disparity in Literacy

\begin{tabular}{|c|c|c|c|c|}
\hline District & Total Literacy Rate & Male Literacy Rate & Female Literacy Rate & $\begin{array}{l}\text { Value of Gender } \\
\text { Disparity Index }\end{array}$ \\
\hline Ambala & 72.27 & 79.91 & 63.66 & 0.15 \\
\hline Bhiwani & 66.92 & 77.27 & 55.10 & 0.22 \\
\hline Faridabad & 70.51 & 82.21 & 57.31 & 0.24 \\
\hline Fatehabad & 55.29 & 63.88 & 45.86 & 0.20 \\
\hline Gurgaon & 76.82 & 87.09 & 65.57 & 0.20 \\
\hline Hisar & 61.14 & 70.76 & 50.13 & 0.21 \\
\hline Jhajjar & 73.51 & 83.57 & 62.05 & 0.20 \\
\hline Jind & 61.34 & 70.58 & 50.67 & 0.21 \\
\hline Kaithal & 58.62 & 67.77 & 48.28 & 0.21 \\
\hline Karnal & 63.95 & 72.36 & 54.47 & 0.18 \\
\hline Kurukshetra & 67.11 & 75.10 & 58.27 & 0.17 \\
\hline Mahendragarh & 74.03 & 86.55 & 60.08 & 0.25 \\
\hline Mewat & 66.82 & 78.38 & 53.81 & 0.24 \\
\hline Palwal & 66.10 & 80.12 & 50.15 & 0.30 \\
\hline Panchkula & 71.59 & 78.30 & 64.00 & 0.14 \\
\hline Panipat & 68.00 & 77.76 & 56.86 & 0.20 \\
\hline Rewari & 75.77 & 87.69 & 62.70 & 0.23 \\
\hline Rohtak & 69.18 & 78.29 & 58.68 & 0.19 \\
\hline Sirsa & 53.97 & 61.23 & 45.98 & 0.17 \\
\hline Sonipat & 70.25 & 79.91 & 59.03 & 0.20 \\
\hline Yamunanagar & 72.31 & 79.35 & 64.31 & 0.14 \\
\hline
\end{tabular}

Source: Census of India 2011, Social and Cultural Tables, Table C-8, SC.

\section{Spatial Pattern of Literacy and Gender Disparity}

Rural literacy rate $(65.75$ per cent $)$ in scheduled caste population is below almost seven per cent from general literacy rate of rural area. It varies from 53.97 per cent in Sirsa to 76.82 per cent in Gurgaon.

Rural male literacy rate (75.10 per cent) in scheduled caste population is below almost eight per cent from general male literacy rate of rural area. It varies from 61.23 per cent in Sirsa to 87.69 per cent in Rewari.

Rural female literacy rate (55.20 per cent) in scheduled caste population is below almost six per cent from general female literacy rate of rural area. It varies from 45.86 per cent in Fatehabad to 65.57 per cent in Gurgaon.

Gender disparity in literacy is presented by gender disparity index. Value of gender disparity index $(0.20$ points) in scheduled caste population of rural area is low 0.01 point from the value of gender disparity index of all rural population. It varies from 0.30 points in Palwal to 0.14 points in Panchkula. 
International Journal of Science and Research (IJSR)

ISSN (Online): 2319-7064

Index Copernicus Value (2015): 78.96 | Impact Factor (2015): 6.391

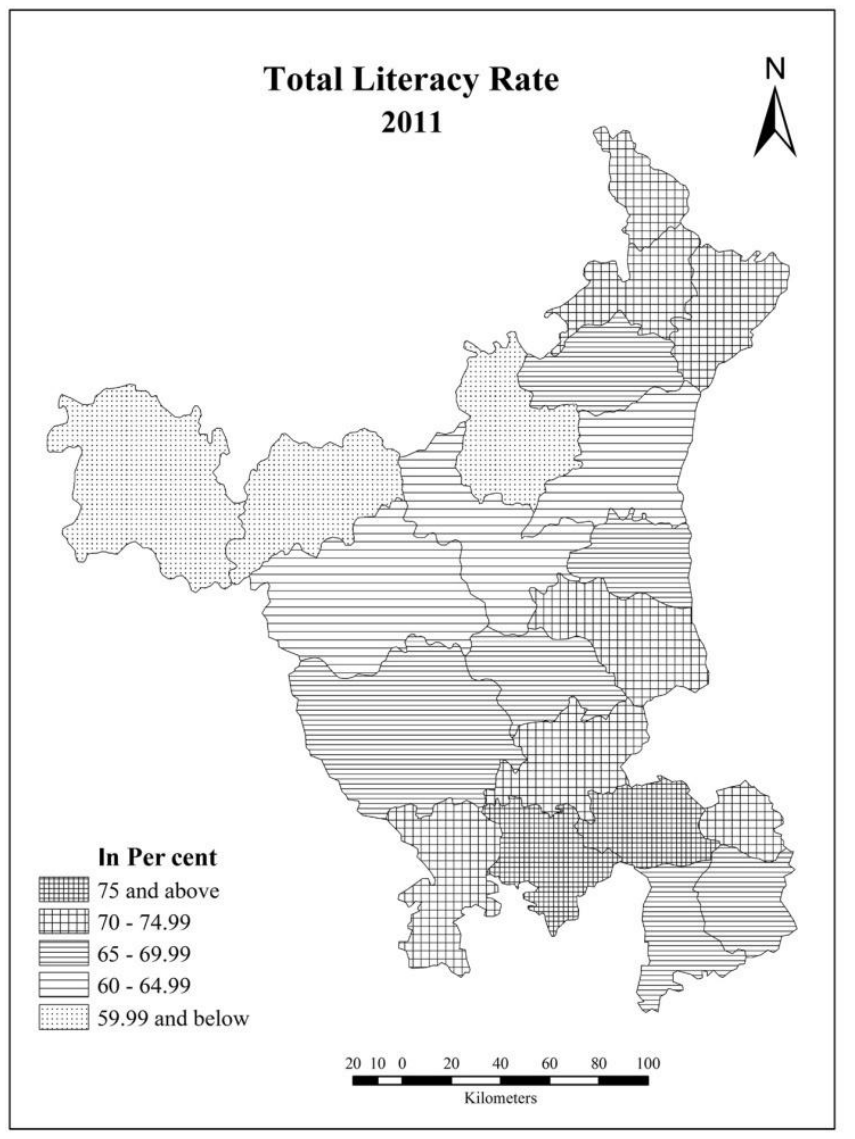

Figure 6

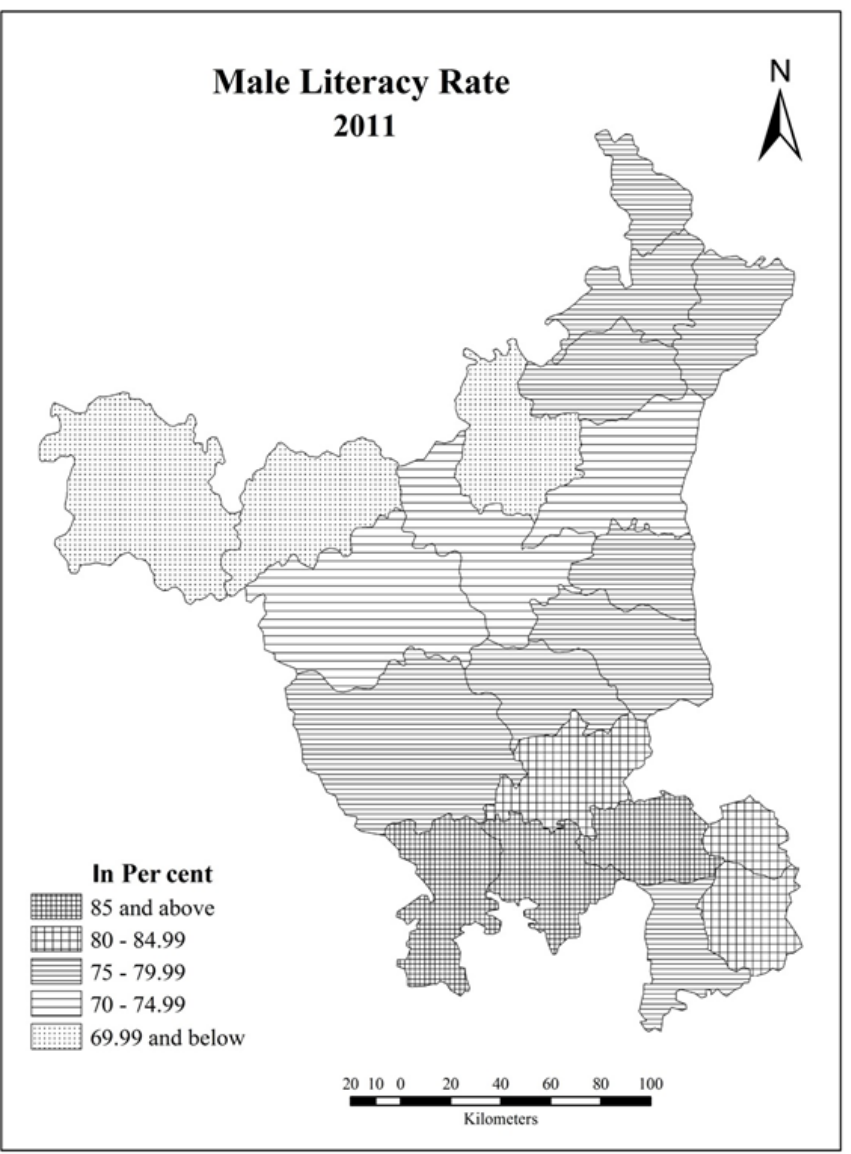

Figure 7

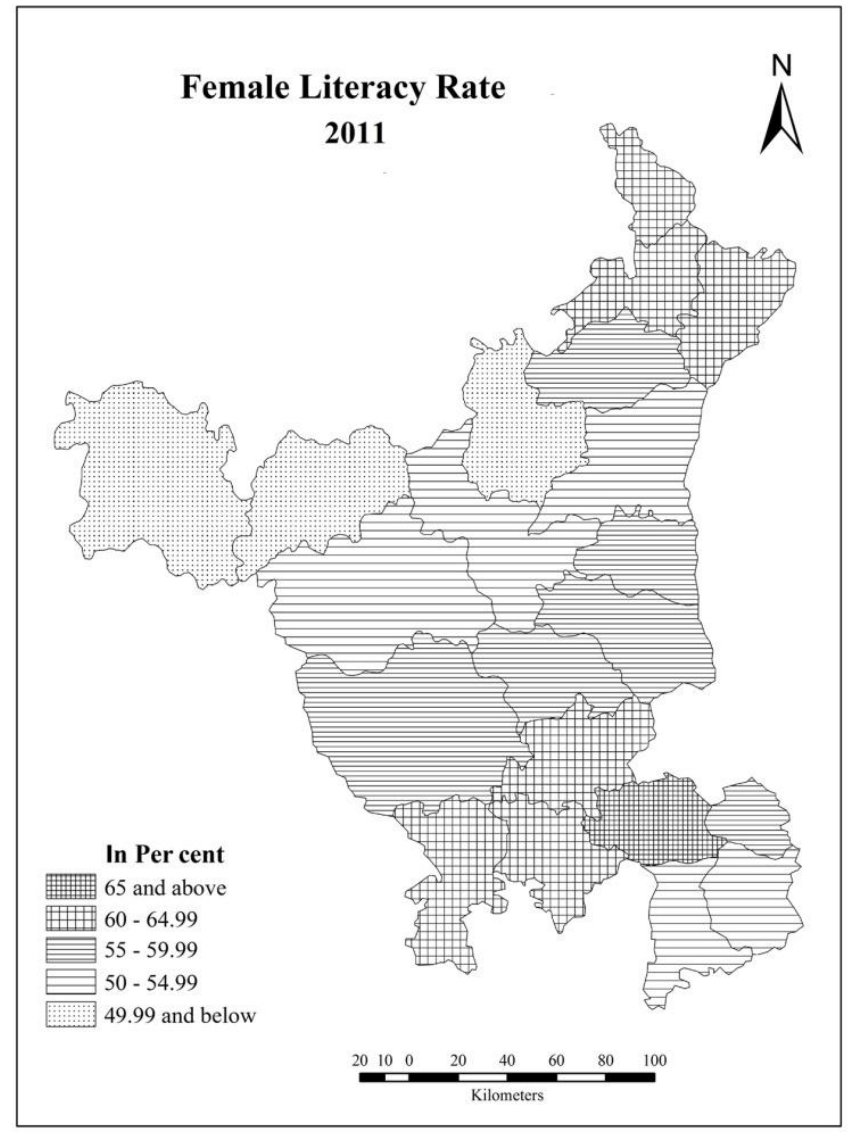

Figure 8

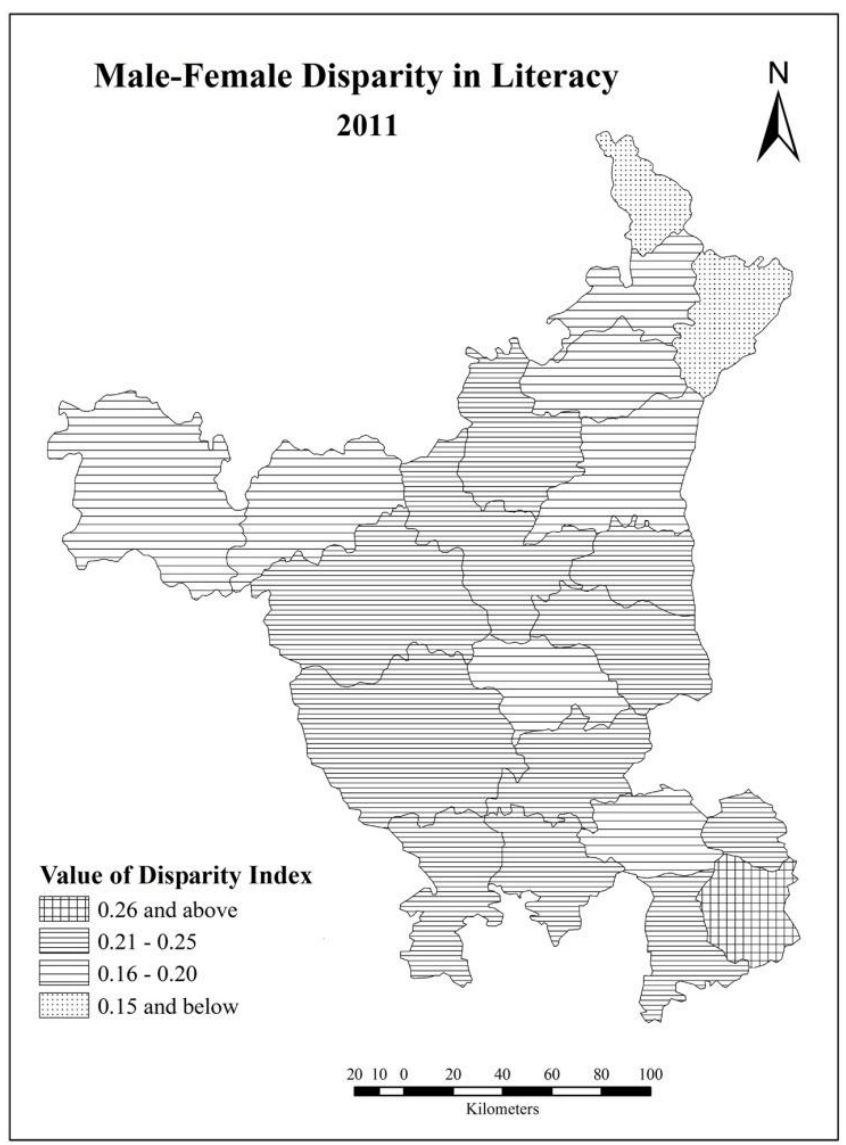

Figure 9

Volume 6 Issue 1, January 2017

www.ijsr.net

Licensed Under Creative Commons Attribution CC BY 


\section{International Journal of Science and Research (IJSR) \\ ISSN (Online): 2319-7064 \\ Index Copernicus Value (2015): 78.96 | Impact Factor (2015): 6.391}

Spatial pattern of rural literacy in sc reflects that Kaithal, Fatehabad and Sirsa are very backward at all levels (total, male and female). Karnal, Jind and Hisar contain low literacy at all levels as well as Mewat and Palwal also contain low female literacy. Northern districts (except male literacy) and the almost districts which are situated around to national capital have high literacy at all levels while rest part has moderate literacy at all levels.
Spatial pattern of gender disparity in literacy reflects that Panchkula and Yamunanagar are only two districts which contain low gender disparity while Palwal has very high gender disparity. Ambala, Kurukshetra, Karnal, Rohtak, Gurgaon, Fatehabad and Sirsa contain moderate gender disparity while rest part has high gender disparity. It is interestingly that Rewari, Mahendragarh and Jhajjar have high male-female literacy as well as high gender disparity.

Table 3: Factors of Correlation

\begin{tabular}{|c|c|c|c|c|c|c|c|c|c|c|}
\hline 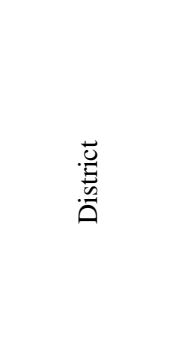 & 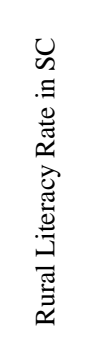 & 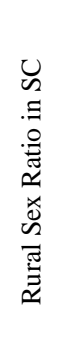 & 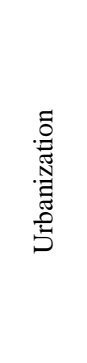 & 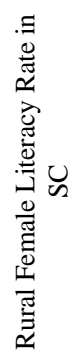 & 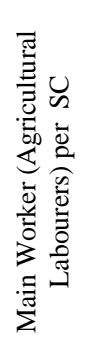 & 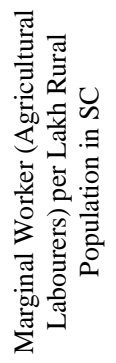 & 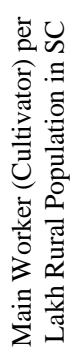 & 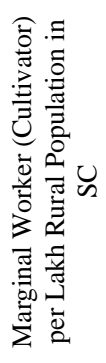 & 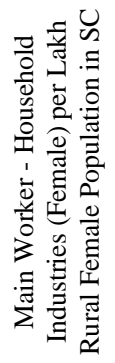 & 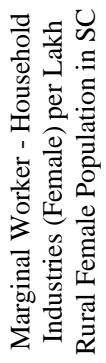 \\
\hline Ambala & 72.27 & 880 & 44.38 & 63.66 & 9277 & 4040 & 1286 & 228 & 212 & 202 \\
\hline Bhiwani & 66.92 & 877 & 19.8 & 55.1 & 9455 & 9613 & 3782 & 1724 & 162 & 579 \\
\hline Faridabad & 70.51 & 885 & 79.44 & 57.31 & 3227 & 2659 & 1254 & 435 & 501 & 680 \\
\hline Fatehabad & 55.29 & 907 & 19.05 & 45.86 & 15181 & 9313 & 2946 & 715 & 200 & 207 \\
\hline Gurgaon & 76.82 & 907 & 68.82 & 65.57 & 4195 & 4888 & 1230 & 507 & 380 & 383 \\
\hline Hisar & 61.14 & 873 & 31.73 & 50.13 & 15335 & 10123 & 2961 & 946 & 253 & 181 \\
\hline Jhajjar & 73.51 & 873 & 25.39 & 62.05 & 6504 & 9596 & 1164 & 623 & 134 & 187 \\
\hline Jind & 61.34 & 866 & 22.82 & 50.67 & 13103 & 10411 & 1715 & 620 & 107 & 116 \\
\hline Kaithal & 58.62 & 882 & 21.97 & 48.28 & 12116 & 9732 & 1130 & 480 & 235 & 306 \\
\hline Karnal & 63.95 & 887 & 30.27 & 54.47 & 12326 & 8740 & 1705 & 306 & 202 & 381 \\
\hline Kurukshetra & 67.11 & 903 & 28.93 & 58.27 & 15287 & 6419 & 1193 & 180 & 179 & 165 \\
\hline Mahendragarh & 74.03 & 893 & 14.43 & 60.08 & 2756 & 8473 & 1144 & 896 & 109 & 148 \\
\hline Mewat & 66.82 & 888 & 11.38 & 53.81 & 3667 & 5392 & 1323 & 418 & 160 & 108 \\
\hline Palwal & 66.1 & 880 & 22.65 & 50.15 & 4932 & 6405 & 1732 & 636 & 125 & 234 \\
\hline Panchkula & 71.59 & 889 & 54.87 & 64 & 4607 & 2525 & 1979 & 1463 & 202 & 574 \\
\hline Panipat & 68 & 875 & 45.97 & 56.86 & 8197 & 7845 & 1094 & 451 & 278 & 240 \\
\hline Rewari & 75.77 & 910 & 25.82 & 62.7 & 2906 & 6653 & 928 & 528 & 375 & 403 \\
\hline Rohtak & 69.18 & 871 & 42.02 & 58.68 & 6778 & 6064 & 1161 & 373 & 196 & 205 \\
\hline Sirsa & 53.97 & 912 & 24.75 & 45.98 & 19281 & 9129 & 3252 & 781 & 225 & 114 \\
\hline Sonipat & 70.25 & 863 & 30.52 & 59.03 & 10111 & 10144 & 968 & 445 & 249 & 359 \\
\hline Yamunanagar & 72.31 & 879 & 38.94 & 64.31 & 11048 & 3937 & 1218 & 136 & 221 & 213 \\
\hline
\end{tabular}

Source: Census of India, Social and Cultural Tables, Table C-8, SC. Urbanization Report (2011), published by Town and Country Planning Organization, Ministry of Urban Development, Government of India, January 2012.

Table 4: Correlation Matrix

\begin{tabular}{|c|c|c|c|c|c|c|c|c|c|c|c|}
\hline Variable & Type of Correlation & $\mathrm{x} 1$ & $\mathrm{x} 2$ & $\mathrm{x} 3$ & $\mathrm{x} 4$ & $\mathrm{x} 5$ & x6 & $\mathrm{x} 7$ & $\mathrm{x} 8$ & $\mathrm{x} 9$ & $\mathrm{x} 10$ \\
\hline $\mathrm{x} 1$ & Pearson Correlation & 1 & -.080 & .419 & $.942^{* *}$ & $-.783^{* * *}$ & $-.537^{*}$ & $-.613^{* *}$ & -.114 & .256 & .314 \\
\hline $\mathrm{x} 2$ & Pearson Correlation & -.080 & 1 & .012 & -.038 & .053 & -.210 & .151 & -.004 & .281 & .012 \\
\hline $\mathrm{x} 3$ & Pearson Correlation & .419 & .012 & 1 & $.489^{*}$ & -.303 & $-.663^{* * *}$ & -.252 & -.141 & $.739^{* * *}$ & $.572^{* *}$ \\
\hline $\mathrm{x} 4$ & Pearson Correlation & $.942^{* *}$ & -.038 & $.489^{*}$ & 1 & $-.595^{* * *}$ & $-.586^{* * *}$ & $-.564^{* * *}$ & -.143 & .244 & .296 \\
\hline $\mathrm{x} 5$ & Pearson Correlation & $-.783^{* * *}$ & .053 & -.303 & $-.595^{* *}$ & 1 & $.524^{*}$ & $.523^{*}$ & -.060 & -.238 & -.388 \\
\hline x6 & Pearson Correlation & $-.537^{*}$ & -.210 & $-.663^{* * *}$ & $-.586^{* *}$ & $.524^{*}$ & 1 & .354 & .200 & -.411 & -.361 \\
\hline $\mathrm{x} 7$ & Pearson Correlation & $-.613^{* * *}$ & .151 & -.252 & $-.564^{* * *}$ & $.523^{*}$ & .354 & 1 & $.690^{* *}$ & -.201 & .078 \\
\hline $\mathrm{x} 8$ & Pearson Correlation & -.114 & -.004 & -.141 & -.143 & -.060 & .200 & $.690^{* * *}$ & 1 & -.210 & .392 \\
\hline $\mathrm{x} 9$ & Pearson Correlation & .256 & .281 & $.739^{* * *}$ & .244 & -.238 & -.411 & -.201 & -.210 & 1 & $.582^{* *}$ \\
\hline $\mathrm{x} 10$ & Pearson Correlation & .314 & .012 & $.572^{* *}$ & .296 & -.388 & -.361 & .078 & .392 & $.582^{* *}$ & 1 \\
\hline
\end{tabular}

**.Correlation is significant at the 0.01 level (2-tailed).

*.Correlation is significant at the 0.05 level (2-tailed). 


\section{International Journal of Science and Research (IJSR) \\ ISSN (Online): 2319-7064}

Index Copernicus Value (2015): 78.96 | Impact Factor (2015): 6.391

Note: Variable $\mathrm{x} 1$ is Rural Literacy Rate in SC, Variable $\mathrm{x} 2$ is Rural Sex Ratio in SC, Variable $\mathrm{x} 3$ is Urbanization, Variable $\mathrm{x} 4$ is Rural Female Literacy Rate in SC, Variable x5 is Main Worker (Agricultural Labourers) per Lakh Rural Population in SC, Variable x6 is Marginal Worker (Agricultural Labourers) per Lakh Rural Population in SC, Variable $\mathrm{x} 7$ is Main Worker (Cultivator) per Lakh Rural Population in SC, Variable $\mathrm{x} 8$ is Marginal Worker (Cultivator) per Lakh Rural Population in SC, Variable x9 is Main Worker - Household Industries (Female) per Lakh Rural Female Population in SC, Variable x10 is Marginal Worker-Household Industries (Female) per Lakh Rural Female Population in SC.

\section{Literacy Correlates}

Correlation between total literacy and female literacy is found very high positively $\left(\mathrm{r}=.942^{* *}\right)$ while its result is found low level positively between total literacy and main and marginal female workers in household industries as well as urbanization.

Correlation between total literacy and main workers (cultivator and agricultural labourers) is found high negatively. Result of correlation is found at moderate level negatively $\left(\mathrm{r}=-.537^{*}\right)$ between total literacy and marginal worker (agricultural labourers) while its results are found very low (negatively) between total literacy and rest factors.

\section{Conclusion}

If we say in few words, rural literacy rate in sc is remaining high in Haryana from India at all levels (total, male and female) during the entire time period (19912011) and its growth rate is recorded very high and almost same in both at all levels during the successive censuses. Gap between male-female literacy is decreased eight per cent in Haryana and six per cent in India during the entire time period however, it is high almost 20 per cent in both at current time. Sirsa, Fatehabad, Kaithal, Hisar, Jind and Karnal have low literacy while all central, south-west and southern districts (except Gurgaon and Rohtak) have high gender disparity in literacy. Correlation between total literacy and female literacy is found very high positively ( $r$ $=.942^{* *}$ ) while it is recorded negatively between total literacy and (cultivator and agricultural labourers).

\section{References}

[1] Urbanization Report (2011): published by Town and Country Planning Organization, Ministry of Urban Development, Government of India.

[2] Census of India (1991): Primary census Abstract, Scheduled caste table.

[3] Census of India (2001): Social and Cultural Tables, Table $C-8$.

[4] Census of India (2011): Provisional population Totals, Paper 1 and 2.

[5] Census of India (2011): Social and Cultural Tables, Table C-8, SC

[6] Gosal, G.S. (1979): "Spatial Perspective on Literacy in India”, Population Geography, 1, pp 41-67.
[7] Hassan, M. I. (2005): Population Geography, Rawat Publications, Jaipur.

[8] Kaur, I. P. (2007): "Social Gains from Female Education in India- An Inter State Analysis", Guru Nanak Journal of Sociology, 28, pp 129-142.

[9] Krishnan, S. R. (2002): "Literacy in India: Current Scenario and Changes during the Last Decade", Demography India, 31, pp 51 - 64.

[10] Kumar, M. and Kumar, V. (2012): "Spatial Pattern and Differential in Literacy: A District Level Analysis of Haryana, 2011", International Journal of Advance Research in Management and Social Sciences, 1, pp 137-145.

[11] Kumar, N. A., \& George, K. K. (2009): "Kerala's Education System: from Inclusion to Exclusion", Economic and Political Weekly, XLIV, pp 55-61.

[12] Panda, S. K. and Devi, S. (1988): "Disparity in Decennial Growth of Literacy in Two Indian States: Analysis", Kurukshetra University Research Journal (Arts and Humanities), XXII, pp 23-31.

[13] Peer, M. (1984): "The Problem of the Educational Backwardness of Indian Muslims", Guru Nanak Journal of Sociology, 5, pp 66-82.

[14] Rabi, A. L. (1990): "Study of Factors Related to Female Illiteracy in Rural Haryana", Kurukshetra University Research Journal (Arts and Humanities), XXIV-XXV, pp 93-96.

[15] Rajakutty, S. (2002): "Primary Education in Rural Areas", Kurukshetra, October 2002, pp 11-20.

[16] Ramachandran, V. (2009): "Right to Education Act: A Comment", Economic and Political Weekly, XLIV, pp 155-157.

[17] Rao, N. (2009): "Structural Constraints in Sarva Shiksha Abhiyan School", Economic and Political Weekly, XLIV, pp 17-20.

[18] Sethi, R. M. (1989): "Role of Non-Formal Educational Schemes in the Education and Empowerment of Women", Guru Nanak Journal of Sociology, 10, pp 147-154.

[19] Sharma, S. (2008): "Empowering Women through Education: Strategy for Sustainable Rural Development", Kurukshetra, 56, pp 3-7.

[20] Sharma, S. and Ghosh, N. (2007): "Progress of School Education, Gender and Imbalances: The Case of Uttarakhand State in India", Demography India, 36, pp 231-251.

[21] Venkatanarayana, M. (2009): "Schooling Deprivation in India", Economic and Political Weekly, XLIV, pp 12-14.

[22] Yadav, R. S. and Panda, S. K. (2004): "Role of Village Education Committees in the promotion of Primary Education in Haryana", $K$. U. Research Journal of Arts \& Humanities, XXXVIII, pp 25-35.

\section{Author Profile}

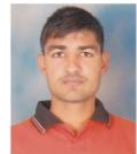

I have done M.PHIL on topic entitled "Literacy Transition: A Comparative Study of Punjab and Haryana (1971-2011) and now pursuing in $\mathrm{Ph} . \mathrm{D}$. on topic entitled "Educational Backwardness in India: A Geographical Analysis" from the Department of Geography, Maharishi Dayanand University, Rohtak, Haryana, India.

\section{Volume 6 Issue 1, January 2017

